\title{
Preparation and evaluation of an ispaghula based directly compressible matrixing agent for controlled release
}

ANITA N. LALWANI ${ }^{1}$

JOLLY R. PARIKH ${ }^{2}$

${ }^{1}$ K. B. Institute of Pharmaceutical

Education and Research

Gandhinagar-382023

Gujarat, India

${ }^{2}$ A. R. College of Pharmacy and

G. H. Patel Institute of Pharmacy

Vallabh Vidyanagar-388120

Gujarat, India
The objective of the present investigation was to prepare and evaluate an ispaghula husk based directly compressible (DC) adjuvant that can be used as matrixing agent using an agglomeration technique. Addition of hydroxypropyl methylcellulose was found necessary to improve cohesion. Lactose (X1), calcium hydrogen phosphate dihydrate (X2) and Avicel PH101 (X3), used along with ispaghula in preparation of agglomerates, were selected as three independent variables in a simplex lattice design affecting compressional and dissolution characteristics of the drug from the DC adjuvant. The agglomerates were evaluated for their flow properties. Tablets were prepared using $70 \%$ agglomerates and 30\% acetaminophen, a poorly compressible drug, and were subjected to in vitro drug release study. Amounts of the drug released at the end of $60 \mathrm{~min}$ (Y60), $300 \mathrm{~min}$ (Y300) and $480 \mathrm{~min}$ (Y480) were selected as dependent variables in a simplex lattice design. Batch IH05 that contained lactose and calcium hydrogen phosphate dihydrate in a 1:2 ratio could control the release for 12 hours and thus form the basis for twice a-day-dosing.

Keywords: simplex lattice design, ispaghula husk, directly compressible, matrixing agent, similarity factor

Sustained drug therapy offers potential advantages, compared to conventional dosage forms, such as avoiding patient compliance problems, improving clinical efficacy, reducing fluctuations in blood and providing cost effectiveness (1). Matrix tablets are among the most widely used oral controlled release systems containing a therapeutic agent, homogenously dissolved or dispersed, in a compressed water-swellable core (2).

Natural materials like ispaghula husk, guar gum and alginates are relatively inexpensive, nontoxic, and easily available. Ispaghula husk (dried seed coat of Plantago ovata (Plantaginaceae)) and guar gum have been used as matrixing agents by researchers for the development of modified release dosage forms (3). In general, such materials are unsuitable for tabletting because of their elasticity, poor flow and compression properties.

*Correspondence, e-mail: anitanlalwani@yahoo.co.in 
A. N. Lalwani and J. R. Parikh: Preparation and evaluation of an ispaghula based directly compressible matrixing agent for controlled release, Acta Pharm. 58 (2008) 309-316.

Ispaghula husk is official in IP, BP and USP. It is used in food and pharmaceuticals at a dose level of 5-7 g twice a day. Ispaghula husk forms a thick swollen gel when kept in contact with water. Additionally, it is fibrous in nature and is poorly compacted (3).

Granulation of the drug and matrixing agent along with the diluents is usually necessary to improve the flowability and compressibility, especially when a high-speed tabletting machine is used. Attempt has been made to provide a method by which the drug can be simply mixed with the matrixing agent and thereafter directly compressed into tablets without granulation. This requires modification of the available matrixing agents to provide tablet materials with ideal properties for tablet production. Researchers have not explored the use of ispaghula husk in the preparation of directly compressible matrixing agents and hence the present study was undertaken.

Modification by co-processing was adopted because the product here is physically modified in a special way, so that it does not lose its chemical structure and stability. This type of modification is cost effective for developing the product, with added value of its functionality.

In this investigation, ispaghula was co-processed with lactose, Avicel PH101 and calcium hydrogen phosphate dihydrate (CHPD) using a simple agglomeration method to prepare a directly compressible (DC) matrixing agent. The slow release excipient was expected to be relatively inexpensive to manufacture due to lack of coating and expensive equipment.

\section{EXPERIMENTAL}

\section{Materials}

Ispaghula husk was purchased from a local pharmacy. Lactose and CHPD were obtained as gift samples from Bombay Tablets, India. Avicel PH101 and polyvinylpyrrolidone were received as gift samples from Torrent Research Centre, India. Hydroxypropyl methylcellulose (HPMC, Methocel K100 LV) was a gift sample from Colorcon Asia Pvt. Ltd., India.

\section{Simplex lattice design for preparation of agglomerates}

Simplex lattice design was utilized in the present study. In this design, three factors were evaluated and exprerimental trials were carried out in ten different combinations. Lactose, CHPD and Avicel PH101 were agglomerated along with HPMC and ispaghula husk powder (80-100 mesh, 177-149 $\mu \mathrm{m}$ ) using an alcoholic solution of polyvinylpyrrolidone $(4 \mathrm{~g}$ in $20 \mathrm{~mL})$. The batch size was $50 \mathrm{~g}$. Ispaghula and HPMC were used in the quantity of $10 \mathrm{~g}$ each. The rest $30 \mathrm{~g}$ were formed of the three excipients in the amounts given in Table I. The amounts of lactose (X1), CHPD (X2) and Avicel PH101 (X3) were selected as independent variables.

The agglomerates were evaluated for the angle of repose and Carr's index. Angle of repose was measured by the fixed funnel method (4). The percentage compressibility (Carr's index) was calculated as 100 times the ratio of the difference between tapped density and bulk density to tapped density (5). 
A. N. Lalwani and J. R. Parikh: Preparation and evaluation of an ispaghula based directly compressible matrixing agent for controlled release, Acta Pharm. 58 (2008) 309-316.

Table I. Actual and transformed values of ten different formulations as per the simplex lattice design

\begin{tabular}{lrrrlll}
\hline & \multicolumn{3}{c}{ Formulation components $(\mathrm{g})$} & \multicolumn{3}{c}{ Transformed fraction } \\
\cline { 2 - 6 } Batch & X1 & X2 & X3 & X1 & X2 & X3 \\
\hline IH01 & 30 & 0 & 0 & 1 & 0 & 0 \\
IH02 & 0 & 30 & 0 & 0 & 1 & 0 \\
IH03 & 0 & 0 & 30 & 0 & 0 & 1 \\
IH04 & 20 & 10 & 0 & 0.66 & 0.33 & 0 \\
IH05 & 10 & 20 & 0 & 0.33 & 0.66 & 0 \\
IH06 & 0 & 20 & 10 & 0 & 0.66 & 0.33 \\
IH07 & 0 & 10 & 20 & 0 & 0.33 & 0.66 \\
IH08 & 10 & 0 & 20 & 0.33 & 0 & 0.66 \\
IH09 & 20 & 0 & 10 & 0.66 & 0 & 0.33 \\
IH10 & 10 & 10 & 10 & 0.33 & 0.33 & 0.33 \\
\hline
\end{tabular}

X1 - lactose, X2 - calcium hydrogen phosphate dihydrate, X3 - Avicel PH101

\section{Preparation of blank tablets}

The agglomerates were blended with 1\% magnesium stearate for 2 min. Tablets were prepared on a single punch tablet machine (Cadmach Machinery Private Limited, India). The average tablet mass was $500 \mathrm{mg}$. The hardness of tablets $(n=10)$ was measured using a Dr. Scleuniger Pharmatron Tablet Tester 8M (Solothurn, Switzerland). Friability was evaluated as the percentage mass loss of 20 tablets tumbled in a friabilator (model EF2, Electrolab, India) for $4 \mathrm{~min}$ at $25 \mathrm{rpm}$. The tablets were then dedusted, and the mass loss caused by fracture or abrasion was recorded as percentage friability (6).

\section{Preparation of tablets with acetaminophen}

Tablets containing $30 \%$ acetaminophen were prepared. Tablets $(n \geq 50)$ containing acetaminophen $(150 \mathrm{mg}$ ) and agglomerates $(350 \mathrm{mg})$, magnesium stearate $(5 \mathrm{mg})$ were prepared and evaluated for hardness and friability.

\section{In vitro dissolution study}

In vitro dissolution study of the tablets was carried out in phosphate buffer ( $\mathrm{pH} 5.8$, $900 \mathrm{~mL}, 37 \pm 0.5^{\circ} \mathrm{C}$ ) by using a USP apparatus (model TDT $-60 \mathrm{~T}$, Electrolab, India) fitted with paddles $(50 \mathrm{rpm})(6)$. Samples $(5 \mathrm{~mL})$ were withdrawn at predetermined time intervals, filtered through $0.45-\mu \mathrm{m}$ filter, and assayed at $246 \mathrm{~nm}$ using a UV/VIS spectrophotometer (Jasco V530, Japan) to determine the percentage of drug released. The same volume $(5 \mathrm{~mL})$ of fresh dissolution medium $\left(37 \pm 0.5^{\circ} \mathrm{C}\right)$ was replenished immediately after the sample was withdrawn. 
A. N. Lalwani and J. R. Parikh: Preparation and evaluation of an ispaghula based directly compressible matrixing agent for controlled release, Acta Pharm. 58 (2008) 309-316.

Table II. Technological and dissolution parameters for the simplex lattice design

\begin{tabular}{cccccc}
\hline Batch & AR $\left({ }^{\circ}\right)$ & CI $(\%)$ & Y60 $(\%)$ & Y300 $(\%)$ & Y480 (\%) \\
\hline IH01 & 36.25 & 12.90 & 28.15 & 72.72 & 93.55 \\
IH02 & 38.33 & 14.29 & 17.02 & 48.72 & 65.21 \\
IH03 & 26.56 & 19.35 & 29.65 & 78.46 & 98.46 \\
IH04 & 30.20 & 12.60 & 28.03 & 67.28 & 81.90 \\
IH05 & 31.00 & 14.50 & 22.65 & 58.52 & 76.59 \\
IH06 & 25.90 & 19.60 & 26.59 & 60.80 & 72.70 \\
IH07 & 25.00 & 19.96 & 28.95 & 68.57 & 85.47 \\
IH08 & 23.00 & 19.67 & 33.52 & 74.25 & 95.46 \\
IH09 & 26.00 & 18.50 & 30.18 & 76.76 & 99.97 \\
IH10 & 26.00 & 17.50 & 45.46 & 80.97 & 99.55 \\
\hline
\end{tabular}

AR - angle of repose, CI - compressibility index.

Y60, Y300 and Y480 indicate the percentage of drug dissolved after 60, 300 and 480 minutes, respectively.

\section{RESULTS AND DISCUSSIONS}

Addition of directly compressible excipients has been used by researchers not only to alter the tablet size but also to improve the compaction and mechanical properties of the tablet (7). Lactose, CHPD and Avicel PH101 were therefore expected to enhance flowability and compressibility. Addition of HPMC improved cohesion during the granulation operations to enlarge the particle size of granules but also during compression to increase the hardness of tablets. The binding ability of HPMC resulted in stronger adhesion between granules (8). Agglomerates of the simplex lattice design were evaluated for the angle of repose and compressibility index. All the batches exhibited the angle of repose less than $40^{\circ}$ and the percentage compressibility index less than 20, indicating fair flow (Table II). Blank tablet hardness was in the range of 50-80 N. The friability value for all the batches was found to be less than $1 \%$. Thus, the agglomerates possessed characteristics that make them suitable for direct compression.

Dilution potential is the ability of the excipient to retain its compressibility even when diluted with a non-compressible material. The agglomerates of the experimental batches were compressed with $30 \%$ acetaminophen, a poorly compressible drug. The hardness of these tablets was 40 to $60 \mathrm{~N}$ and friability values were less than $1 \%$ for all the experimental batches. This indicates that inspite of dilution with acetaminophen, the tablets fulfilled the hardness and friability criteria.

The ability of the DC matrixing agent to provide controlled release was tested using an in vitro dissolution study. The in vitro dissolution study of the tablets was carried out to find the amount of drug released at the end of $60 \mathrm{~min}$ (Y60), $300 \mathrm{~min}$ (Y300) and 480 min (Y480). A first-order statistical model incorporating interactive terms was utilized to evaluate these responses:

$$
Y=b_{1} X 1+b_{2} X 2+b_{3} X 3+b_{12} X 1 X 2+b_{13} X 1 X 3+b_{23} X 2 X 3+b_{123} X 1 X 2 X 3
$$


A. N. Lalwani and J. R. Parikh: Preparation and evaluation of an ispaghula based directly compressible matrixing agent for controlled release, Acta Pharm. 58 (2008) 309-316.

where $b_{\mathrm{i}}(i=1,2,3 \ldots 123)$ is the estimated coefficient for the factor Xi. Multiple linear regression analysis was done using the Design Expert ${ }^{\circledR}$ 6.0.5 Trial (Statease statistical software package). The main effects (X1, X2 and X3) represent the average results of changing one factor at a time from its low to its high value. Interactions $X 1 X 2, X 2 X 3, X 1 X 3$ and $\mathrm{X} 1 \mathrm{X} 2 \mathrm{X} 3$ show how the response changes when the two or three factors change simultaneously.

Results of the multiple regression analysis are shown in Table III. Avicel PH101 and lactose had higher values of the coefficient in the equation used to describle Y60, Y300 and Y480 while calcium hydrogen phosphate had a lower value. Avicel PH101 had a stronger effect than lactose in increasing the dissolution rate, as indicated by the equation coefficients. Lactose, being freely soluble, will dissolve and provide a pathway for diffusion of the drug and erosion of the matrix, leading to fast release of the drug from the matrix tablet. Although Avicel PH101 and CHPD are water-insoluble, Avicel PH101 has disintegrating properties that promote disintegration of the matrix and therefore the matrix will easily erode compared to CHPD. In addition, CHPD tablets do not disintegrate readily. Therefore, matrices containing CHPD would have less tendency to erode compared to Avicel PH101 and consequently slower release rate. Ladipus and Lordi (9) postulated that the presence of high levels of insoluble diluents reduced release rates by increasing the tortuosity of the matrix, whereas the addition of a soluble diluent (lactose) merely reduced the tortuosity of the matrix, thereby increasing the dissolution rates. Use of a combination of lactose/Avicel PH101 and CHPD produced drug release profiles of intermediate duration. The dissolution profiles of batch $\mathrm{IH} 05$ (containing 33\% lactose) and IH06 (containing 33\% Avicel PH101) which contain 66\% CHPD were essentially similar similarity factor $(f 2=71.26)$. When CHPD was present at lower levels (33\%), IH04 (containing 66\% lactose) and IH07 (containing 66\% Avicel PH101), no appreciable difference in dissolution profile was found $(f 2=84.27)$, indicating that the pres-

Table III. Results of the regression analysis for dependent variables

\begin{tabular}{ccccrrrrr}
\hline $\begin{array}{c}\text { Dependent } \\
\text { variables }\end{array}$ & $b_{1}$ & $b_{2}$ & $b_{3}$ & $b_{12}$ & $b_{23}$ & $b_{31}$ & $b_{123}$ & $R^{2}$ \\
\hline Y60 & 27.99 & 17.03 & 29.80 & 14.02 & 21.07 & 14.90 & 426.45 & 0.9853 \\
Y300 & 73.46 & 48.89 & 77.55 & 10.72 & 9.64 & 3.47 & 345.28 & 0.9866 \\
Y480 & 93.85 & 65.53 & 97.85 & 1.63 & -8.20 & 12.98 & 388.70 & 0.9798 \\
\hline
\end{tabular}

Table IV. Results of the model fitting of batch IH05

\begin{tabular}{lcc}
\hline Kinetic model & $R^{2}$ & $F$-value \\
\hline Zero-order & 0.9439 & 45.24 \\
First-order & 0.9849 & 10.44 \\
Higuchi & 0.9858 & 6.60 \\
Korsmeyer and Peppas & 0.9872 & 6.45 \\
Hixon-Crowell & 0.9802 & 18.91 \\
Weibull & 0.9951 & 1.74 \\
\hline
\end{tabular}


A. N. Lalwani and J. R. Parikh: Preparation and evaluation of an ispaghula based directly compressible matrixing agent for controlled release, Acta Pharm. 58 (2008) 309-316.

ence of lactose or Avicel PH101 does have an effect depending on their proportion and the two are interchangeable.

An ideal modified release dosage form, intended to be given twice a day, should release the loading dose (25\%) in the first hour and later (up to $12 \mathrm{~h}$ ) the remaining drug should be released at a constant rate $\left(6.82 \% \mathrm{~h}^{-1}\right)(3)$. The ideal release profile was calculated as per the set criteria. According to the US FDA guidelines for similarity factor (f2) calculations, two dissolution profiles are considered as identical if the calculated $\mathrm{f} 2$ value is greater than or equal to 50 . This value is calculated considering $10 \%$ deviation between a reference and a test formulation. The value of $\mathrm{f} 2$ is equal to 100 when the two dissolution profiles are identical.

The dissolution profile of batch IH05, containing lactose and CHPD in 1:2 ratio along with ispaghula husk powder and HPMC, was similar to the ideal release profile (f2 $=64.40$ corresponding to $5 \%$ difference). Fig. 1 shows the dissolution profile of batch IH05 and the ideal release profile.

The ideal values for a twice-a-day drug formulation as per the above mentioned criteria for Y60, Y300 and Y480 are 25.0\%,59.1\% and 72.7\% respectively. To widen the scope of selection, the following constraints were chosen for the selection of acceptable batches: $15 \%<\mathrm{Y} 60<25 \%, 55 \%<\mathrm{Y} 300<65 \%, 70 \%<\mathrm{Y} 480<80 \%$. Contour plots were drawn using the above-mentioned constraints for dissolution in 60 (Y60), 300 (Y300) and 480 (Y480) $\mathrm{min}$ as per the respective equations. Optimization was performed by superimposing the three contour plots and locating the area of interest (Fig. 2). Any combination that falls in this area (shaded black) will satisfy the selected constraints of dissolution. It is worthwhile noting that batch IH05 lies in this area.

The dissolution data of batch IH05 was fitted to zero-order, first-order, Higuchi (10), Hixson-Crowell (11), Korsmeyer and Peppas (12), and Weibull models (13). The method of Bamba et al. (14) was adopted for deciding on the most appropriate model. The results of F-statistics were used to select the most appropriate model. The release profile of batch IH05 fitted best to the Weibull model $(F=1.74)$. This superiority is statistically insignificant with the Korsmeyer and Peppas model $(F=6.45)$ and Higuchi model $(F=$ 6.60), as shown by the goodness-of-fit test. But, priority should be given to the model with the lowest $F$-value. Thus, it may be concluded that drug release of acetaminophen from the matrix tablet is best explained by the Weibull model. The value of the slope for

Fig. 1. Comparison of in vitro dissolution profiles of batch IH05 and the ideal release profile (mean $\pm \mathrm{SD} ; n=3$ ).

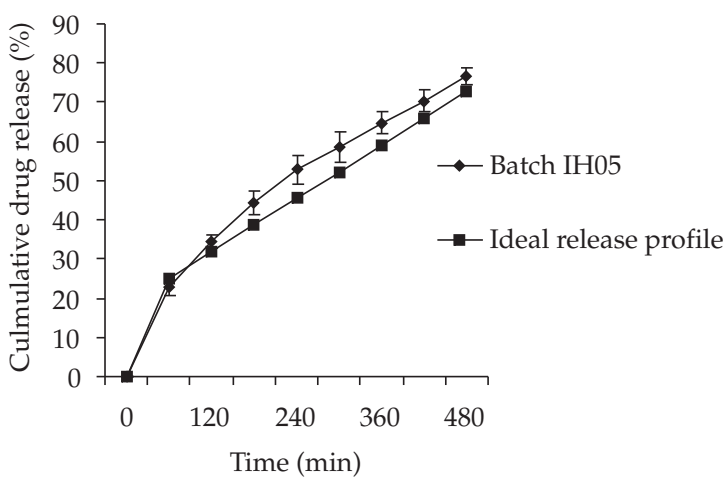


Fig. 2. Contour curves for Y60 (R1), Y300 (R2) and Y480 (R3) (X1 - lactose, $\mathrm{X} 2$ - calcium hydrogen phosphate dihydrate, X3 - Avicel PH101).

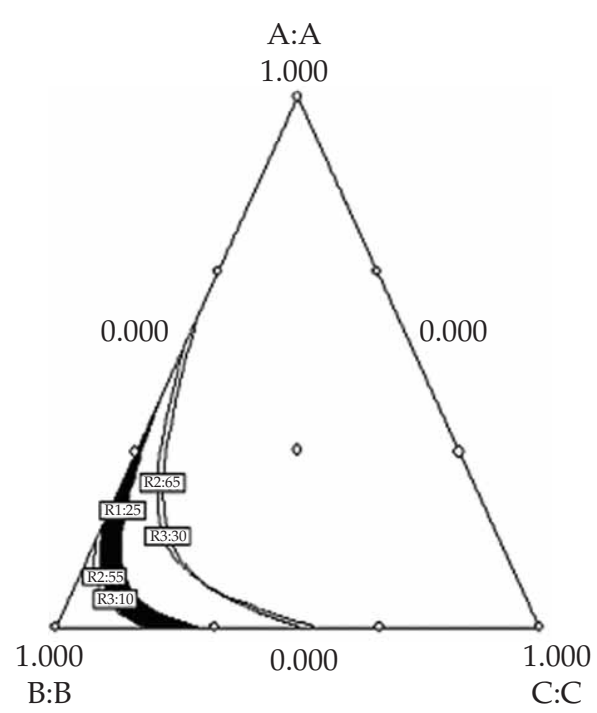

the Korsmeyer and Peppas model is 0.6232 , indicating that the drug was released by diffusion of an anomalous type.

\section{CONCLUSIONS}

The present study indicates that ispaghula husk can be used as matrixing agent along with lactose, CHPD and Avicel PH101 to produce a DC adjuvant with sustained release properties. A proper proportion of the release enhancer (lactose/Avicel PH101) and release retardant (CHPD) can be selected from the contour plot to produce the desired dissolution profile. The statistical technique thus enables formulation scientists to examine more than one independent variable at a time. Desirable goals can be obtained by a systematic approach in the shortest possible time.

\section{REFERENCES}

1. M. N. V. Ravikumar and N. Kumar, Polymeric controlled drug delivery systems: Perspective issues and opportunities, Drug Dev. Ind. Pharm. 27 (2001) 1-30; DOI:10.1081/DDC-100000124.

2. D. S. Hsieh, W. Rhine and R. Langer, Zero order controlled-release polymer matrices and macromolecules, J. Pharm. Sci. 72 (1983) 17-22; DOI:10.1002/jps.2600720105.

3. M. C. Gohel, M. M. Patel and A. F. Amin, Development of modified release diltiazem $\mathrm{HCl}$ tablets using composite index to identify optimal formulation, Drug Dev. Ind. Pharm. 29 (2003) 565-574; DOI:10.1081/DDC-120018645.

4. A. Mckenna and D. F. McCafferty, Effect of particle size on the compaction mechanism and tensile strength of tablets, J. Pharm. Pharmacol. 34 (1982) 347-351.

5. R. L. Carr, Evaluating flow properties of solids, Chem. Eng. 72 (1965) 163-168. 
A. N. Lalwani and J. R. Parikh: Preparation and evaluation of an ispaghula based directly compressible matrixing agent for controlled release, Acta Pharm. 58 (2008) 309-316.

6. Unated States Pharmacopeia 24, National Formulary 19, USP Convention, Rockville, 2000.

7. O. A. Odeku and J. T. Fell, Evaluation of Khaya gum as directly compressible matrix system for controlled release, J. Pharm. Pharmacol. 56 (2004) 1365-1370; DOI: 10.1211/0022357044652.

8. H. Ho, H. Wang and M. Sheu, The evaluation of granulated excipients as matrix material for controlled delivery of captopril, J. Control. Release 49 (1997) 243-251; DOI: 10.1016/S0168-3659 (97)00093-X.

9. H. Ladipus and N. G. Lordi, Drug release from compressed hydrophilic matrices, J. Pharm. Sci. 57 (1968) 1292-1301; DOI: 10.1002/jps.2600570803.

10. T. Higuchi, Rate of release of medicaments from ointment bases containing drugs in suspension, J. Pharm. Sci. 50 (1961) 874-875; DOI: 10.1002/jps.2600501018.

11. R. Korsmeyer, R. Gunny and N. Peppas, Mechanism of solute release from porous hydrophilic polymers, Int. J. Pharm. 15 (1983) 25-35; DOI: 10.1016/0378-5173(83)90064-9.

12. A. W. Hixson and J. H. Crowell, Dependence of reaction velocity upon surface and agitation, Ind. Eng. Chem. 23 (1931) 923-931; DOI: 10.1021/ie50260a018.

13. F. Langenbucher, Linearisation of dissolution rate curves by the Weibull distribution, J. Pharm. Pharmacol. 24 (1972) 979-981.

14. M. Bamba and F. Puisieusx, Release mechanisms in gel forming sustained release preparation, Int. J. Pharm. 2 (1979) 307-315; DOI: 10.1016/0378-5173(79)90037-1.

\section{$S A \check{Z} E T A K$}

\section{Priprava i vrednovanje matriksnog agensa na bazi ispagule za kontrolirano oslobađanje}

ANITA N. LALWANI i JOLLY R. PARIKH

Cilj rada bila je priprava i vrednovanje pomoćne tvari za izravnu kompresiju dobivene iz ljuski ispagule, primjenjive $u$ izradi pripravaka metodom aglomeracije. Dodatak hidroksipropil metilceluloze bio je neophodan za povećanje kohezije. U pripravi aglomerata s ispagulom upotrebljeni su laktoza (X1), kalcijev hidrogenfosfat dihidrat (X2) i Avicel PH101 (X3). U eksperimentalnom dizajnu (simplex lattice design) te tri tvari izabrane su kao nezavisne varijable. Proučavan je njihov utjecaj na kompresibilnost i oslobađanje ljekovite tvari iz pripravka dobivenih izravnom kompresijom te svojstva tečnosti aglomerata. Tako dobiveni aglomerati upotrebljeni su za pripravu tableta teško kompresibilne tvari acetaminofena (omjer aglomerata i ljekovite tvari 7:3). Količine oslobođene tvari in vitro pri kraju 60 min (Y60), 300 min (Y300) i 480 min (Y480) bile su zavisne varijable. Iz pripravka IH05 koji sadrži laktozu i kalcijev hidrogenfosfat dihidrat u omjeru 1:2 kontrolirano se oslobađa ljekovita tvar tijekom 12 sati, što je dobar temelj za doziranje dva puta dnevno.

Ključne riječi: simplex lattice design, ljuske ispagule, izravno kompresibilan, matriksna tvar, faktor sličnosti

\section{K. B. Institute of Pharmaceutical Education and Research, Gandhinagar-382 023, Gujarat, India}

A. R. College of Pharmacy and G. H. Patel Institute of Pharmacy, Vallabh Vidyanagar-388 120, Gujarat, India 